\title{
Dynamic models for transient stability analysis of transmission and distribution systems with distributed generation : an overview
}

Citation for published version (APA):

Boemer, J. C., Gibescu, M., \& Kling, W. L. (2009). Dynamic models for transient stability analysis of transmission and distribution systems with distributed generation : an overview. In Proceedings of the IEEE Bucharest PowerTech 2009, June 28 - July 2, 2009, Bucharest, Romania (pp. 1-8). Institute of Electrical and Electronics Engineers. https://doi.org/10.1109/PTC.2009.5282177

DOI:

10.1109/PTC.2009.5282177

Document status and date:

Published: 01/01/2009

Document Version:

Publisher's PDF, also known as Version of Record (includes final page, issue and volume numbers)

Please check the document version of this publication:

- A submitted manuscript is the version of the article upon submission and before peer-review. There can be important differences between the submitted version and the official published version of record. People interested in the research are advised to contact the author for the final version of the publication, or visit the $\mathrm{DOI}$ to the publisher's website.

- The final author version and the galley proof are versions of the publication after peer review.

- The final published version features the final layout of the paper including the volume, issue and page numbers.

Link to publication

\footnotetext{
General rights

- You may freely distribute the URL identifying the publication in the public portal. follow below link for the End User Agreement:

www.tue.nl/taverne

Take down policy

If you believe that this document breaches copyright please contact us at:

openaccess@tue.nl

providing details and we will investigate your claim.
}

Copyright and moral rights for the publications made accessible in the public portal are retained by the authors and/or other copyright owners and it is a condition of accessing publications that users recognise and abide by the legal requirements associated with these rights.

- Users may download and print one copy of any publication from the public portal for the purpose of private study or research.

- You may not further distribute the material or use it for any profit-making activity or commercial gain

If the publication is distributed under the terms of Article $25 \mathrm{fa}$ of the Dutch Copyright Act, indicated by the "Taverne" license above, please 


\title{
Dynamic Models for Transient Stability Analysis of Transmission and Distribution Systems with Distributed Generation: an overview
}

\author{
Jens C. Boemer, Member, IEEE, and Madeleine Gibescu, Member, IEEE, \\ Wil L. Kling, Member, IEEE
}

\begin{abstract}
Distributed Generation is increasing in nowadays power systems. Small scale systems such as photovoltaic, biomass or small cogeneration plants are connected to the distribution level, while large wind farms will be connected to the transmission level. Both trends lead to a replacement of large synchronous generators as the dominating generation technology. Up to now, transient stability of transmission systems has been analysed to a satisfactory degree of accuracy with a simplified representation of the distribution systems. In future, distributed generation will more and more influence the behaviour of the system. Stiff, inverter-based local generation technologies may improve the system stability; however, increasing electrical distances between large synchronous generators in operation will impede the system stability. These (and other) diverging effects have to be studied in detail. This overview paper summarises the latest findings and reveals future research questions. It is concluded that the accuracy and validity of the currently applied dynamic models for transient stability analysis of power systems with high penetration of DG should be further investigated.
\end{abstract}

Index Terms - Distributed generation, Load modelling, Nonlinear systems, Power distribution, Power system dynamic stability, Power transmission, Reduced order models

\section{INTRODUCTION}

$\mathrm{D}$ ISTRIBUTED Generation (DG) [1] is increasing in nowadays power systems, mainly due to effective support schemes for renewable energy and cogeneration. Existing power systems may be or may not be suitable to include a certain amount of DG without harming the power system stability. Several high level studies analysed the impacts of DG on the power system design and operation [2], [3]. However, only recently also transient phenomena are being studied in detail [4], [5]. One interesting phenomena is transient stability.

Jens. C. Boemer is with the Electrical Power Systems Group, Delft University of Technology. He is also working with the Power Systems and Markets Group of Ecofys Germany GmbH, Stralauer Platz 34, D-10243 Berlin, Germany (e-mail: J.C.Boemer@tudelft.nl).

Madeleine Gibescu is with the Electrical Power Systems Group, Delft University of Technology, 2600 CD Delft, The Netherlands (e-mail: m.gibescu@tudelft.nl).

W. L. Kling is with the Electrical Power Systems Group, Delft University of Technology, 2600 CD Delft, The Netherlands. He is also with the Electrical Power Systems Group, Eindhoven University of Technology, 5612 AZ Eindhoven, The Netherlands (e-mail: w.l.kling@tudelft.nl).
Kundur [6] introduced the following definition: Transient stability is the ability of the power system to maintain synchronism when subjected to a severe transient disturbance.

Transient phenomena may become important when the penetration of DG increases over a certain limit. Whereas stiff inverter based generation technologies may improve the system stability, the increasing electrical distances between the remaining large synchronous generators (SG) in operation may impede the system stability. For studying these effects, a variety of dynamic models of power systems with high penetration of DG have been developed. However, such models are not yet standardized. Their large variety represents the current research of their respective authors or research groups. Generally accepted - and most importantly: validated - models still do not exist.

The variety observed in the existing dynamic DG models was also found in the power system stability studies performed. In the existing literature, a number of assumptions that influence the study results have been identified from which the most important ones are:

- What level of DG penetration was studied?

- What types of models for DG were used?

- What control systems did the DG models include?

- What behaviour of DG was assumed during grid faults?

- What types of models were used for loads?

- In what detail was the transmission system, respectively the distribution system modelled?

- Were network reduction techniques or simplified equivalent network representations used?

This overview paper summarises in section II the results from previous work. It covers DG and load models as well as studies on transient stability analysis for power systems with high amounts of DG. The findings from section II are critically reviewed in section III and from that the problems related to adequate representation of the distribution systems are defined. Section IV presents the questions that must be answered in order to systematically solve the identified problems and, hence, a need for future research is revealed. Conclusions are given in section V. 


\section{PREVIOUS WORK}

\section{A. Modelling of $D G$}

DG covers a wide range of technologies. The models presented here have been developed for power system stability studies of various kinds, including transient stability.

The first DG units that have been modelled were directly coupled rotating generators such as simple asynchronous generators and small SG (subsection 1). Following, models for various inverter-coupled devices such as micro turbines and fuel cells were reported (subsection 2). The most extensive modelling task has been the modelling of wind turbines (subsection 3). The latter will be of particular importance since wind energy takes the largest part of currently installed DG in modern power systems.

\section{1) Rotating generators}

a) Small synchronous generators

Donnelly et al. presented a model and its parameters for a gas-turbine-driven $60 \mathrm{MW}$ generator [7]. The generator was assumed to have either a brushless high initial response excitation system or a static exciter with a power system stabilizer, and a fast-acting turbine/governor system. The excitation system based on [8]-[6].

Edwards et al. also presented a model for gas-turbinedriven SG of the 5 to $25 \mathrm{MW}$ scale [9] including parameters for the generator and exciter. The subtransient model with two rotor circuits in each axis also considered the machine saturation. A standard IEEE T1 exciter model was used to represent a brushless alternating current (AC) exciter with a rotating rectifier. A speed governor/turbine system model based on the fundamental model of [10] was used.

Guttromson et al. used standard SG models [11] attached to IEEE ST1 static exciters and adapted their parameters to DG.

Slootweg et al. used standard PSS/E models according to [12] and applied standard exciter and governor models from [6]. The reactive power limits were defined by a power factor $\cos (\varphi)=0.9$ leading and lagging. Prime movers were not modelled since irrelevant for transient stability studies.

Azmy et al. modelled a two machine transmission system and used similar models of SG with IEEE standard regulators for speed governors and excitation systems [13].

Tran-Quoc et al. used 0.04 to 5 MVA sized micro-turbines with a model representing the rotating machine, the governor, and the excitation system with four equivalent windings [14].

In general it can be noted that the order of the models found in the literature varies and is only seldom well documented.

\section{b) Asynchronous generators}

Asynchronous generators are well understood machines and standard models have been implemented in various software packages. For example, Slootweg et al. used in [15] standard models based on [6] and implemented in PSS/E according to according to [12].

c) Inverter coupled devices

Slootweg et al. modelled inverter coupled devices with a general model as controllable sources of active and reactive power [15]. This was justified by the fact that the grid representation in power system dynamics simulations software and the typical time step used did not allow for detailed modelling of power electronics and its controllers [15].

d) Micro turbines

Azmy et al. proposed in [13] a dynamic model for a 0.3 to $0.8 \mathrm{MW}$ micro-turbine consisting of three parts: compressor, combustor, and the turbine. The turbine drives a permanent magnet synchronous generator (PMSG) that is connected to its shaft without a gearbox. The generator is represented by a simple $1^{\text {st }}$ order model. Since the frequency of the micro turbine is very high, it is connected to the grid via a full converter. The latter can regulate the reactive power independently from the active power of the unit.

e) Fuel cells

Azmy et al. proposed in [16] a fuel cell model consisting of the following three parts: reformer, stack, and the inverter. For the stability studies, a $3^{\text {rd }}$ order non-linear equivalent circuit dynamic model was proposed to approximate the fuel cell dynamics as seen from the network side.

\section{2) Wind turbines}

a) Fixed-speed wind turbines (SCIG)

Sørensen et al. presented in [17] a verified model for a typical "Danish concept" wind turbine with a two speed squirrel cage induction generator (SCIG), a soft-starter and capacitor banks for reactive power compensation.

Akhmatov presented models for fixed-speed wind turbines in [18].

b) Doubly-fed induction generator models

Akhmatov et al. presented in [19]-[20] a doubly-fed induction generator (DFIG) model suitable for the investigation of dynamic interactions between the variablespeed wind turbines equipped with DFIG and the power grid. However, it was assumed that the modeled wind turbine was disconnected in case of a grid fault.

Pöller presented in [21] a DFIG model suited for stability analysis of large power systems. Its components were the DFIG, the grid-side converter, the rotor-side converter, the aerodynamic behavior of the wind turbine and the pitch control system. The rotor current protection used a "crowbar" to bypass the rotor-side converter during faults near to the generator, so the model included a basic fault ride through (FRT) capability.

Hughes et al. presented in [22] an advanced model for DFIG that facilitates FRT based on the "crowbar" approach. The model also allowed for provision of frequency support.

Similarly, Michalke et al. presented in [23]-[24] a DFIG model that also uses a "crowbar" for FRT.

A further step in the modelling of DFIG is presented by Erlich et al. in [25]-[26] where the turbines are modelled in such detail that their behaviour during ride through of grid faults can be analysed. It was shown that with a properly designed "crowbar" and a DC-link "chopper" even zero voltage ride-through was possible. Besides modelling of a single DFIG the authors also applied in [27] their models for analysis of a complete (offshore) wind farm connected via a long $\mathrm{AC}$ cable to the transmission system. 
c) Direct drive synchronous generator models

Direct drive synchronous generators (DDSG) can either be PMSG or wound rotor synchronous generators (WRSG), depending on the excitation used. Both are coupled to the grid via a full converter.

Michalke et al. presented in [23]-[24] a model for a PMSG equipped with FRT capability. The power surplus of the turbine that cannot be delivered to the grid during the fault causes acceleration and oscillations of the drive train. To avoid such oscillations, a "chopper" was added to the DC-link of the full converter.

Slootweg et al. presented in [28] a model for a WRSG based on [6]. However, this model does not include FRT.

d) General models

Slootweg et al. introduced in [29] a general model for representing the two most common variable-speed wind turbines in power system dynamics simulations, i.e. DFIG and DDSG (no differentiation was made between PMSG and WRSG). Previously, the authors had concluded in [30] that after some simplifications that are necessary to derive a transient model for use in power system dynamics simulations, the differences between the two generator types used cannot be seen in their interaction with the grid anymore. The reason was that the differences were fully compensated for by the controllers. Therefore, it was possible to replace the generator by a controllable torque source, enabling the representation of both variable-speed wind turbine types with a universal model.

The simplifications taken for developing the general model assumed that the terminal voltage approximately equals the nominal value; since this assumption was not met during grid faults, the presented general model could not be used for grid fault studies. The model was therefore limited to simulation of power system dynamics where only small disturbances occur.

Slootweg et al also presented in [28] a well documented collection of models for the most commonly used wind turbines. However, none of these models include detailed modelling of FRT capabilities.

\section{3) Aggregation of models and further references}

The modeling of individual wind turbines in a wind farm will increase the computation time in transient stability studies significantly. Since this is not desirable, wind park models with aggregated wind turbine behavior and respective simplifications were proposed.

An aggregated model for fixed-speed wind turbines that can be used to study and improve the power plant characteristics of the wind farm has been presented by Sørensen et al. in [17]. Slootweg et al. presented in [31]-[32] an aggregated park model extended to variable-speed wind turbines. Akhmatov et al. concluded that the aggregation of the wind farm should be made dependent on the operation point [33]. Rudion proposed in [34] a reduction of wind farm models using a coherency approach that is independent from the generator type but depends on wind speed direction.

Eventually, as a good compromise between detailed and simplified wind farm models for dynamic power system studies, Pöller et al. [35] proposed a variable-speed wind turbine model that aggregated only the electrical system, including the electrical controls and the electrical part of the generators; the mechanical system of each individual turbine and generator remained modelled individually, in order to achieve sufficient accuracy in longer term dynamics. However, for the time frame of the transient stability phenomena, this level of detail is not obligatory.

An overview on the modelling of DFIG is presented in Table I. A state-of-the-art CIGRE report on modelling and dynamic behaviour of wind generation as it relates to power system control and dynamic performance is given in [36].

TABLE I

WIND TURBINES MODELS

\begin{tabular}{|c|c|c|c|c|c|}
\hline References & SCIG & DFIG & $\begin{array}{l}\text { PMS } \\
\text { G }\end{array}$ & $\begin{array}{l}\text { FRT } \\
\text { included }\end{array}$ & $\begin{array}{l}\text { Wind Farm } \\
\text { Model }\end{array}$ \\
\hline $\begin{array}{l}\text { Sørensen/Hansen } \\
\text { et al. [17] }\end{array}$ & $\mathrm{X}$ & - & - & No & Yes \\
\hline $\begin{array}{l}\text { Akhmatov et al. } \\
{[19],[20] \text { and }} \\
{[33]}\end{array}$ & (X) & $\mathrm{X}$ & (X) & No & $\begin{array}{l}\text { Operation } \\
\text { dependent } \\
\text { aggregation }\end{array}$ \\
\hline $\begin{array}{l}\text { Pöller et al. } \\
{[21] \text { and [35] }}\end{array}$ & - & $\mathrm{X}$ & - & Crowbar & $\begin{array}{l}\text { Aggregation } \\
\text { of electrical } \\
\text { system }\end{array}$ \\
\hline $\begin{array}{l}\text { Hughes et al. } \\
{[22]}\end{array}$ & - & $\mathrm{X}$ & - & Crowbar & $\begin{array}{l}\text { Total } \\
\text { aggregation }\end{array}$ \\
\hline $\begin{array}{l}\text { Erlich et al. } \\
{[25],[27] \text {, and }} \\
{[26]}\end{array}$ & & & & Chopper & $\begin{array}{l}\text { Total } \\
\text { aggregation }\end{array}$ \\
\hline $\begin{array}{l}\text { Michalke/Hansen } \\
\text { [23] and [24] }\end{array}$ & - & $\mathrm{X}$ & $\mathrm{X}$ & $\begin{array}{l}\text { Crowbar } \\
\text { for DFIG / } \\
\text { Chopper } \\
\text { for PMSG }\end{array}$ & $\begin{array}{l}\text { Total } \\
\text { aggregation }\end{array}$ \\
\hline $\begin{array}{l}\text { Slootweg et al. } \\
{[29],[30],[28],} \\
{[31] \text { and }[32]}\end{array}$ & (X) & $\mathrm{X}$ & (X) & No & $\begin{array}{l}\text { Aggregation } \\
\text { of electrical } \\
\text { system }\end{array}$ \\
\hline $\begin{array}{l}\text { Rudion } \\
{[34]}\end{array}$ & - & - & - & No & $\begin{array}{l}\text { Aggregation } \\
\text { according to } \\
\text { coherency } \\
\text { approach }\end{array}$ \\
\hline
\end{tabular}

B. Modelling of loads

A general overview on load representation for dynamic performance analysis of power system was given in [37]. In [38] standard load models for power flow and dynamic simulation programs were recommended; the latter included recommendations on the structure of multiple load types connected to a load bus for transient stability, longer-term dynamics, and small-disturbance stability studies. A major challenge remained always in finding the numerical values for voltage and frequency dependency; however, this has been successfully achieved in [39] for Germany.

Traditionally, lumped feeder loads are represented as static composite load models on the basis of constant impedance (Z), constant current (I) or constant power (P) contributions, also called ZIP-loads. Further improvements of these models resulted in a classical dynamic model that was, however, still linear in its voltage and frequency dependence of active and reactive power. To overcome the drawbacks of linearity, Kermendey et al. proposed in [40] a more advanced load model (Fig. 1). The model contained of a static part being 
purely dependent on supply voltage and load current, realised by a voltage dependent impedance, and an induction motor model.

The static part is frequency independent, since it was found that differentiating between static and dynamic part regarding frequency is practically impossible [40]. For the composite load model the frequency dependency was therefore fully described by the speed-torque characteristic of the dynamic load model contribution. The main outcome of a voltage stability study for a power system with a very high motor load (nearly $60 \%$ ) was that the dynamic load model with linear dependence of active and reactive power on voltage and frequency showed a too optimistic voltage response.

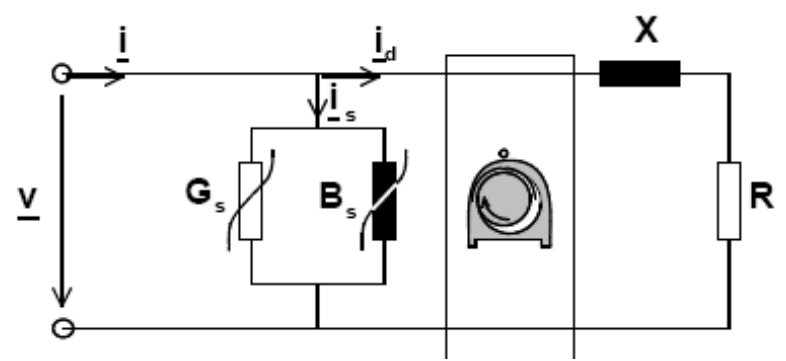

Fig. 1 Load Model with static and dynamic load [40]

Vaahedi et al. studied in [41] the effect of dynamic versus static load modelling in large transient stability studies. The model was ultimately a dynamic model consisting of an equivalent induction machine in parallel with a static model, similar to [40]. The model was validated using measurement data from severe disturbances. Two cases were studied: a severe disturbance in a strong interconnected system and another in a system with heavy industrial loads, weak interconnections and, therefore, significantly higher number of frequency and voltage deviations. In the former case, the findings showed that the dynamic load representation changes the calculated response only marginally. But in the latter case noticeable differences between results obtained with the static and dynamic load model were observed and the dynamic model showed much better accuracy. The authors concluded that for weak systems with high frequency and voltage deviations, dynamic load models should be used.

Borghetti et al. in [42] also used a load model based on a static load plus an aggregate of induction motors, similar to Fig. 1 and [40]. The behaviour of three simplified models were compared: a generic non-linear dynamic model of the first order, a static exponential load plus a dynamic first-order model for the induction motors, and a static exponential load plus a dynamic third-order model for the induction motors. It was shown that for the same disturbance the simulation results were quite different from each other and, in certain cases, only the third-order dynamic model for the induction motor correctly predicted the voltage collapse at the load bus. However, it should be noted that the voltage collapse was outside the time frame of the transient stability.

The presented studies showed the complexity of load modelling and, to a certain extent, the sensitivity of the stability results. Although [40] and [41] concluded that in certain cases only dynamic load models showed the severity of the instability, [42] and [43] concluded that transient stability studies with static load models would show rather conservative results for the stability limits. Some general conclusions are:

- For transient stability analysis in strong and well interconnected power systems, static load models that are only voltage dependent are sufficient.

- For transient stability analysis in weak power systems, voltage and frequency dependent static and dynamic load models for the representation of asynchronous motors are needed.

- For voltage stability analysis, dynamic load models that include additionally the slower transients are needed.

\section{Modelling of distribution systems with loads and DG}

Since [40]-[43] deal only with load modelling it must be investigated furthermore how sensitive the adequate representation of the distribution systems with high penetration of DG is, with respect to the chosen order of the DG models. Certainly, it might be favourable to model distribution systems and all their connected DG in detail; however, that would increase the computational effort for transmission system wide transient stability studies considerably. A good balance between detail and simplification must be found.

Only a single publication was found that systematically described models for representation of distribution systems with DG. Azmy et al. used in [44] recurrent artificial neural networks ANNs to identify dynamic equivalents for distribution networks that contain large amounts of DG. Passive elements, i.e. loads, were represented as lumped equivalent elements at the boundary nodes as constant impedance whereas recurrent ANNs represented the dynamic response of active DG units. The authors showed that the obtained equivalent model was able to capture the dynamic behaviour of the replaced distribution network in its entirety. Good conformity with the results obtained using the full dynamic model of the distribution network was achieved, even under new generation and loading conditions. However, only fuel cells and micro turbines were considered as DG.

\section{Transient power system stability studies}

From the previous work on transient stability analysis of power systems, the influences of DG as shown in Table II can be derived. The following effects improve transient stability:

- Loading of large SG in the transmission system is reduced.

- Loading of transmission lines is reduced.

- Imbalances between generation and loads during network disturbances are reduced.

- The mechanical system of inverter based DG is decoupled from the electrical system. 
However, the following effects may have a negative impact on transient stability:

- DG units have much lower inertia than large SG.

- Some DG units (e.g. wind turbines) have a less controllable power output and cannot be used to dampen oscillations in the power system over time frames as long as the large power plants can.

Most effects are related to the DG units' lower inertia constant; it leads on one hand to DG units' lower inherent transient stability and on the other hand to their ability to respond to system changes quicker than large SGs would do. It can be observed that oscillation frequencies of the transients in the power system after a disturbance are higher with high amounts of DG [7], [13].

In general, most of the studies revealed that the transient stability of the overall transmission system is improved by DG. One reason is that DG is installed close to the loads (as a side effect, system losses are decreased). This reduces the loading of the transmission system and that moves the system farther away from its stability limit. However, the picture depends on how the large SG are treated, namely whether they are either taken out of operation or reduced in their rated power. In the first case the electrical distances between the remaining large SG increase and that reduces their electromechanical coupling, i.e. the system stability decreases. In the second case, if their rating is lower, the large SG become smaller relatively to the impedance of the grid which in turns strengthens the mutual electromechanical coupling between the large SG [45], i.e. the system stability is improved.

TABLE II

INFLUENCE OF DG ON TRANSIENT STABILITY

\begin{tabular}{|l|l|l|}
\hline Implication & Explanation & Study \\
\hline $\begin{array}{l}\text { - DG units } \\
\text { themselves have an } \\
\text { unfavourable } \\
\text { transient stability. }\end{array}$ & $\begin{array}{l}\text { - DG have lower inertia than large } \\
\text { SG, and the lower the DG inertia } \\
\text { the lower their transient stability. }\end{array}$ & {$\left[\begin{array}{l}{[9],[13],} \\
{[14],[46]}\end{array}\right.$} \\
\hline $\begin{array}{l}\text { - DG increases the } \\
\text { oscillation } \\
\text { frequency after a } \\
\text { disturbance. }\end{array}$ & $\begin{array}{l}\text { - DG units have lower inertia than } \\
\text { large SG. }\end{array}$ & {$[7][13]$} \\
\hline $\begin{array}{l}\text { DG can improve } \\
\text { the transient } \\
\text { stability of the } \\
\text { transmission } \\
\text { system. }\end{array}$ & $\begin{array}{l}\text { - DG units are installed close to the } \\
\text { loads and, therefore, } \\
\text { reduce power flows in the } \\
\text { transmission system, and } \\
\text { reduce the imbalance between } \\
\text { generation and loads during a } \\
\text { network disturbance. }\end{array}$ & {$[7],[13]$,} \\
\hline $\begin{array}{l}\text { DG units' loss of } \\
\text { synchronism has } \\
\text { less impact on } \\
\text { power system than } \\
\text { the tripping of } \\
\text { large SG. }\end{array}$ & $\begin{array}{l}\text { DG have much lower rated power } \\
\text { than large SG and, therefore, their } \\
\text { (individual) tripping causes less } \\
\text { transients in the power system. }\end{array}$ & {$[14]$} \\
\hline
\end{tabular}

The transient stability margins of DG themselves are low; but individually their tripping would cause less transients in the power system. However, to really make use of DG to increase the transient stability of the overall transmission system, reference [13] concludes that the stability of the individual DG units themselves has to be improved. This could be done, for example, by

- increasing the DG's inertia, e.g. via a fly wheel,

- using advanced control systems to emulate inertia, e.g. for wind turbines, or

- designing the DG more robust so that it can trip without being damaged.

Further differentiation for the implications of various generator technologies according to [15] are necessary to fully depict the results achieved in previous work. It was found that SCIG do not have a large influence on transient stability, because the following two effects counterbalance each other:

- when SCIG are located near large SG, the speeding up of the large SG during a fault increases the SCIG's stator frequency which in turn decreases the slip frequency and that reduces the SCIG's power output. The decrease in generation from SCIG slows down the large SG.

- when SCIG are located at larger distance to large SG, the speeding up of the SCIG during a fault increases its slip frequency which in turn increases its reactive power demand and that leads to lower terminal voltages at the large SG nodes. The lower voltage reduces the large SG's synchronising torque and that can speed up the large SG.

Furthermore it was found in [15] that small SG units improve the transient stability of a power system. One reason for this is that they keep up their excitation during a fault and that keeps up the synchronising torque between the other SG in the power system. However, uncontrolled SG can have a negative impact on the oscillation duration; in [15] it was assumed that this may be due to inter-area oscillations but that statement was not further proven. It was finally shown that controlled SG units have a slightly negative impact on the oscillation duration after disturbances.

With regard to power electronic converters it was concluded in [15] that they improve the transient stability of power systems. But this was explained via the disconnection of the devices during a fault. If no FRT capability is available, this results in loss of generation capacity and that in turn decreases the maximum rotor speed deviation of the remaining SG. Similar to the small SG it was found that uncontrolled power electronic converters negatively increase the oscillation duration (although the authors assumed that the major reason behind it were the large SG governor models and their parameters); in contrast, controlled power electronic converters could slightly decrease the oscillation duration through adequate damping.

A thorough analysis of the transient stability of transmission systems with high penetration of DG was done by Reza in [47]; characteristics of different types of DG and also storage technologies were treated. The author performed transient stability analysis of a model transmission system based on the variables "maximum rotor speed deviation" and "oscillation duration" (instead of using the widely accepted "critical clearing angle" and "critical clearing time"). Furthermore, the work assessed effects of generation dispatch which will mainly become effective as soon as the DG takes 
over power generation from conventional power plants as described in the introduction of this paper. Reza found:

- At DG penetration levels of up to around $30 \%$ in terms of share in total generation capacity no significant stability problems occur; stability is even improved due to lower line power flows.

- As soon as the optimal power flow shuts down existing conventional plants, the inertia of the total system decreases and stability problems occur in some cases.

A critical review of Reza's work shows that the transient analysis is performed with a rather simplified representation of the underlying distribution networks; it is also assumed that each distribution network only contains one single type of DG.

With regard to the transient stability of distribution systems, Ishchenko developed in [46] simplified dynamic models of distribution networks with DG, seeking for their linearization and then applying among others Hankel norm approximation methods for model reduction. For a comparison between the various reduction techniques analysed by Ishchenko refer to Table III. Based upon these methods, the work assesses transient stability for the very first time and in a well documented systematic manner for distribution networks with DG. Ishchenko found:

- Linearization and model reduction of distribution networks with DG are appropriate and reliable under certain assumptions.

- The steady-state stability of distribution grid is lower than for transmission grid due to a higher $\mathrm{R} / \mathrm{X}$ value.

- The transient stability analysis proves that the closer the fault is to the substation of the distribution network, the worse becomes the stability (or in other words: the lower must be the critical clearing time). This is explained by rather slow voltage restoration compared to faults at the branches of individual DGs.

Having analyzed all previously mentioned publications, it must be stressed that the validation of the study results is of major importance. Not all authors went this last step. For this purpose, it is noted that the medium voltage distribution network for investigation of DG integration as presented in [48] may become helpful for benchmarking results.

TABLE III

COMPARISON OF VARIOUS MODEL REDUCTION METHODS [46]

\begin{tabular}{|c|c|c|c|}
\hline \multicolumn{2}{|c|}{$\begin{array}{c}\text { Singular Value Decomposition- } \\
\text { based methods }\end{array}$} & \multicolumn{2}{c|}{ Krylov methods } \\
\hline Advantages & Drawbacks & Advantages & Drawbacks \\
\hline Error is bounded & $\begin{array}{c}\text { Not applicable } \\
\text { for very large } \\
\text { systems }\end{array}$ & $\begin{array}{c}\text { Applicable for } \\
\text { very large } \\
\text { systems }\end{array}$ & $\begin{array}{c}\text { Error is not } \\
\text { bounded }\end{array}$ \\
$\begin{array}{c}\text { Stability is } \\
\text { preserved }\end{array}$ & $\begin{array}{c}\text { Requires } \\
\text { calculation of } \\
\text { singular values } \\
\text { of the original } \\
\text { system }\end{array}$ & $\begin{array}{c}\text { Numerically } \\
\text { efficient }\end{array}$ & $\begin{array}{c}\text { Stability is not } \\
\text { preserved }\end{array}$ \\
\hline
\end{tabular}

\section{PROBLEM DEFINITION}

A critical review of the previously presented studies leads to the following list of observations on the current research:

- Only for small SG, asynchronous generators and micro turbines standard models exist for adequate representation of DG. For SG coupled via an inverter or other more complex DG such as DFIG etc., a variety of non-standardised models exist. The latter are not widely included into power system simulation packages.

- If DFIG were modelled, most of the time no FRT had been implemented. Grid voltage support during the fault was even more rarely modelled.

- The overlaying transmission system has been modelled as a strong - sometimes even as an infinite - voltage source, neglecting the weakening effect that comes with high penetrations of DG.

- Many DG were modelled without reactive power or power factor control.

- Only low order models have been widely used for DG that do not capture all effects (including medium term transients).

- Loads have been modelled as static loads with voltage and frequency dependence but dynamic modelling of loads has been seldom. Thus, the dynamic behaviour of asynchronous motors was not taken into account.

- Distribution systems only contained loads but active parts such as the dynamics of DG were nearly never considered in a large scale study.

- Model reduction techniques widely used linearization that prevents the obtained simulation results to be generalised for large disturbances.

More general, the following two problems can be defined:

1. Structural change in power systems:

- Whereas nowadays transmission systems are strong and can be modelled as a (nearly) infinite source in distribution system studies, transmission systems in the future will become weaker and their actual behaviour may affect significantly the behaviour of underlying distribution systems.

- Whereas nowadays distribution systems are mainly modelled with a simplified load model, a more detailed representation of them is needed since DG may reach a high penetration in (certain) distribution systems.

2. Technology change in power systems:

- Increasing levels of DG are replacing large SG as the dominating generation technology

- On one hand, stiff inverter-based generation technologies will improve the system stability

- On the other hand the increasing electrical distances between synchronous generators in operation and the reduced system inertia will impede the system stability.

- The resulting diverging effects have to be studied in detail.

The presented previous work shows that further research is needed to assess the transient stability of future transmission systems including distribution systems with high penetration of DG. The overall goal of future research should be the finding of an adequate aggregated representation of a 
distribution system with static and dynamic loads as well as different DG technologies, e. g. DFIG and generation coupled via full inverters. These representations should be applicable to large power system studies.

\section{OPEN Questions}

The following list shows the open questions that should be systematically assessed when solving the proposed problems.

- What are the limitations of existing models for dynamic simulation of power systems with high penetration of DG in terms of accuracy and performance? What is a good trade-off between the two?

- What are the important aspects of power electronics interfaces in the DG networks that should be modelled for stability studies of the transmission system (overcurrent protection, FRT, inertia emulation etc.)?

- From what DG penetration level a more appropriate representation of the distribution system becomes vital?

- What mathematical methods exist for dealing with high-order non-linear dynamic system models? Which of these have been applied to power systems so far and which not (and why)?

\section{CONCLUSION}

This overview paper summarised the results from previous work on DG and load modelling as well as studies of the transient stability analysis for power systems with high amounts of DG. The findings were critically reviewed and the problems related to adequate representation of the distribution systems defined. Two main problems were highlighted: First, transmission systems become weaker and distribution systems contain more DG - both resulting in fewer possibilities for simplification of the respective system. Second, a technology change with large SG with high inertia being replaced by DG with either low inertia or with mechanical parts completely decoupled from the grid via an inverter - that results in reduced power system stability on one hand and smaller impact of frequency deviations on the predominating generators on the other hand. Finally, questions that should be systematically assessed when solving the proposed problems were presented. In conclusion, the accuracy and validity of the currently applied dynamic models for transient stability analysis of power systems with high penetration of DG should be further investigated.

\section{REFERENCES}

[1] T. Ackermann, G. Andersson, and L. Söder, "Distributed generation: a definition," Electric Power Systems Research, vol. 57, no. 3, pp. 195 204, 2001.

[2] M. O'Malley, C. Nabe, J. Bömer, and D. Broad, "The irish "all island grid study" - methodological approach and outcomes," in 2009 Power Systems Conference and Exposition, March 15-18, 2009, Seattle, Washington, USA. Ecofys Germany GmbH, 2009.

[3] Project Steering Group, "Planning of the grid integration of wind energy in germany onshore and offshore up to the year 2020 (dena grid study)," Deutsche Energie-Agentur GmbH, Tech. Rep., February 2005.

[4] H. Lemmens and W. Winter, "European wind integration study (EWIS). EWIS-interim report," European Transmission System Operators, Tech. Rep., 2008.
[5] H. Holttinen, P. Meibom, A. Orths, F. van Hulle, B. Lange, A. Tiedemann, M. O’Malley, J. Pierik, B. Ummels, J. O. Tande, A. Estanqueiro, M. Matos, E. Gomez, L. Söder, G. Strbac, A. Shakoor, J. C. Smith, M. Milligan, and E. Ela, "Task 25 - design and operation of power systems with large amounts of wind power. final report, phase one 2006-08 (draft)," 2009, Implementing Agreement for Co-operation in the Research, Development, and Deployment of Wind Energy Systems.

[6] P. Kundur, Power system stability and control. New York: McGrawHill, 1994.

[7] M. Donnelly, J. Dagle, D. Trudnowski, and G. Rogers, "Impacts of the distributed utility on transmission system stability," vol. 11, no. 2, pp. 741-746, 1996.

[8] IEEE Power Engineering Society, "IEEE recommended practice for excitation system models for power system stability studies," The Institute for Electrical and Electronics Engineers, 345 E. 47th St., New York, NY, IEEE Standard 421.5-1992, March 1992.

[9] F. Edwards, G. Dudgeon, J. McDonald, and W. Leithead, "Dynamics of distribution networks with distributed generation," in Proc. IEEE Power Engineering Society Summer Meeting, vol. 2, 2000, pp. 10321037 vol. 2.

[10] W. Rowen, "Simplified mathematical representations of heavy-duty gas-turbines," Journal of Engineering For Power-Transactions of the ASME, vol. 105, no. 4, pp. 865-869, 1983.

[11] R. Guttromson, "Modeling distributed energy resource dynamics on the transmission system," vol. 17, no. 4, pp. 1148-1153, 2002.

[12] PSS/E 25, On-line Documentation, Power Technologies, Inc., Schenectady, US, December 1997.

[13] A. Azmy and I. Erlich, "Impact of distributed generation on the stability of electrical power system," in Proc. IEEE Power Engineering Society General Meeting, 2005, pp. 1056-1063 Vol. 2.

[14] T. Tran-Quoc, L. Le Thanh, C. Andrieu, N. Hadjsaid, C. Kieny, J. C. Sabonnadiere, K. Le, O. Devaux, and O. Chilard, "Stability analysis for the distribution networks with distributed generation," in Proc. 2005/2006 IEEE/PES Transmission \& Distribution Conference \& Exposition, vol. 1-3, Dallas, TX, USA, May 21-26 2006, Proceedings Paper, pp. 289-294.

[15] J. Slootweg and W. Kling, "Impacts of distributed generation on power system transient stability," in Proc. IEEE Power Engineering Society Summer Meeting, vol. 2, 2002, pp. 862-867 vol.2.

[16] A. Azmy and E. Erlich, "Dynamic simulation of fuel cells and microturbines integrated ith a multi-machine network," in Proc. IEE Power Tech, vol. 2. Italy: Bologna, June 23-26 2003, pp. 550-555.

[17] P. Sørensen, A. Hansen, L. Janosi, J. Bech, and B. Bak-Jensen, "Simulation of interaction between wind farm and power system," Risoe, Tech. Rep., 2001, risoe-R-128(EN).

[18] V. Akhmatov, "Analysis of dynamic behaviour of electric power systems with large amount of wind power," Ph.D. dissertation, ØrestadDTU, Denmark, 2003.

[19] V. Akhmatov and H. Knudsen, "Advanced simulation of windmills in the electric power supply," International Journal of Electrical Power Systems and Energy Systems, vol. 22, no. 6, pp. 421-434, 2000.

[20] V. Akhmatov, "Variable-speed wind turbine with doubly-fed induction generators part i: modelling in dynamic simulation tools," Wind Engineering, vol. 26, no. 2, pp. 85-108, 2002.

[21] M. Pöller, "Doubly-fed induction machine models for stability assessment of wind farms," in Proc. IEEE Bologna Power Tech, vol. 3, 2003, pp. 6 pp. Vol.3-.

[22] F. Hughes, O. Anaya-Lara, N. Jenkins, and G. Strbac, "Control of DFIG-based wind generation for power network support," IEEE Transactions on Power Systems, vol. 20, no. 4, pp. 1958-1966, NOV 2005.

[23] G. Michalke, A. D. Hansen, and T. Hartkopf, "Variable speed wind turbines - modeling, control and impact on power systems," in Proc. European Wind Energy Conference EWEC, 31 March - 3 April 2008 2008.

[24] G. Michalke, "Variable speed wind turbines - modelling, control, and impact on power systems," Ph.D. dissertation, TU Darmstadt, 1 August 2008.

[25] I. Erlich and F. Shewarega, "Modeling of wind turbines equipped with doubly-fed induction machines for power system stability studies," in Proc. IEEE PES Power Systems Conference and Exposition PSCE '06, 2006, pp. 978-985. 
[26] I. Erlich, H. Wrede, and C. Feltes, "Dynamic behavior of DFIG-based wind turbines during grid faults," in Power Conversion Conference Nagoya, 2007. PCC'07, H. Wrede, Ed., 2007, pp. 1195-1200.

[27] I. Erlich, J. Kretschmann, J. Fortmann, S. Mueller-Engelhardt, and $\mathrm{H}$. Wrede, "Modeling of wind turbines based on doubly-fed induction generators for power system stability studies," IEEE Transactions on Power Systems, vol. 22, no. 3, pp. 909-919, 2007.

[28] J. G. Slootweg, H. Polinder, and W. L. Kling, "Representing wind turbine electrical generating systems in fundamental frequency simulations," IEEE Transaction on Energy Conversion, vol. 18, no. 4, pp. 516-524, Dec. 2003.

[29] J. G. Slootweg, S. W. H. de Haan, H. Polinder, and W. L. Kling, "General model for representing variable speed wind turbines in power system dynamics simulations," IEEE Transactions on Power Systems, vol. 18 , no. 1, pp. 144-151, February 2003.

[30] J. G. Slootweg, S. W. H. de Haan, H. Polinder, and W. L. Kling, "Modeling wind turbines in power system dynamics simulations," in IEEE Power Engineering Society Summer Meeting, Vancouver, Canada, 15-19 July 2001.

[31] J. Slootweg, S. W. H. de Haan, H. Polinder, and W. L. Kling, "Aggregated modeling of wind park with variable speed wind turbines in power system dynamics simulations," in 14th Power Systems Computation Conference, Sevilla, Spain, 24-28 June 2002, 2002.

[32] J. Slootweg and W. L. Kling, "Aggregated modelling of wind parks in plower system dynamics simulations," in Proc. IEEE Bologna PowerTech Conference, Bologna, Italy, June 23-26 2003.

[33] V. Akhmatov and H. Knudsen, "Aggregate model of a grid-connected, large-scale, offshore wind farm for power stability investigationsimportance of windmill mechanical system," International Journal of Electrical Power Systems and Energy Systems, vol. 25, no. 9, pp. 707719, 2002.

[34] K. Rudion, "Reduction of wind farm models using the coherency approach," in Proc. Power Systems Computational Conference 2008, Glasgow, 2008.

[35] M. Pöller and S. Achilles, "Aggregated wind park models for analyzing power system dynamics," in Proc. 4th International Workshop on Large-Scale Integration of Wind Power and Transmission Networks for Offshore Wind Farms, Billund, Denmark, 2003.

[36] W. G. C4.601, "Modeling and dynamic behavior of wind generation as it relates to power system control and dynamic performance," International Council on Large Electric Systems (CIGRE), Tech. Rep., August 2007.

[37] IEEE Task Force on Load Representation for Dynamic Performance, "Load representation for dynamic performance analysis [of power systems]," IEEE Transactions on Power Systems, vol. 8, no. 2, pp. 472-482, 1993.

[38] IEEE Task Force on Load Representation for Dynamic Performance, "Standard load models for power flow and dynamic performance simulation," IEEE Transactions on Power Systems, vol. 10, no. 3, pp. 1302-1313, August 1995, System Dynamic Performance Subcommittee \& Power System Engineering Committee.

[39] E. Welfonder, B. Hall, W. Glaunsinger, and R. Hueck, "Untersuchung der frequenz- und spannungsabhängigen Leistungsaufnahme von Verbraucherteilnetzen - Ergebnisse und Folgerungen für den Verbundbetrieb. (investigation of the frequency and voltage dependent power absorption by consumer sub-networks - results and conclusions for the interconnected system operation)," Elektrizitätswirtschaft, vol. 93, pp. 81-87, 1994

[40] E. Kermendey, N. Villalobos, and M. Schmieg, "The impact of load behavior on voltage stability, an application case in Enelven / Venezuela," $1999 . \quad$ [Online]. Available: http://www.digsilent.de/Consulting/Publications/andescon.pdf

[41] E. Vaahedi, H. El-Din, and W. Price, "Dynamic load modeling in large scale stability studies," IEEE Transactions on Power Systems, vol. 3, no. 3, pp. 1039-1045, 1988.

[42] A. Borghetti, R. Caldon, A. Mari, and C. Nucci, "On dynamic load models for voltage stability studies," IEEE Transactions on Power Systems, vol. 12, no. 1, pp. 293-303, 1997.

[43] Z. Hongbin, H. Renmu, L. Li, and Z. Jian, "Application of different load models for the transient stability calculation," in Proc. International Conference on Power System Technology PowerCon 2002, vol. 4, 2002, pp. 2014-2018 vol.4.
[44] A. Azmy and I. Erlich, "Identification of dynamic equivalents for distribution power networks using recurrent ANNs," in Proceedings of the IEEE PES Power Systems Conference \& Exposition, New York City, USA, October 2004.

[45] J. G. Slootweg and W. L. Kling, "The impact of large scale wind power generation on power system oscillations," Electric Power Systems Research, vol. 67, no. 1, pp. 9-20, Oct. 2003.

[46] A. Ishchenko, "Dynamics and stability of distribution networks with dispersed generation," Ph.D. dissertation, Technische Universiteit Eindhoven, January 2008.

[47] M. Reza, "Stability analysis of transmission systems with high penetration of distributed generation," Ph.D. dissertation, Delft University of Technology, December 2006.

[48] K. Rudion, A. Orths, Z. Styczynski, and K. Strunz, "Design of benchmark of medium voltage distribution network for investigation of DG integration," in Proc. IEEE Power Engineering Society General Meeting, 2006.

\section{BIOGRAPHIES}

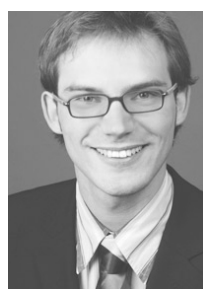

Jens Bömer received his Dipl.-Ing. in Electrical Engineering from Technical University of Dortmund, Germany in 2005. He specialised on power systems and renewable energies. In 2006-2007 he advised as an independent consultant the German Environment Ministry on policies for improved grid integration of wind turbines and other renewable energy resources. Since September 2007 he works as a Consultant in the Power Systems and Markets Group at the Ecofys office in Berlin. Parallel to his employment at Ecofys, Mr Bömer is Ph.D.-candidate with the Department of Electrical Power Engineering, Delft University of Technology, The Netherlands.

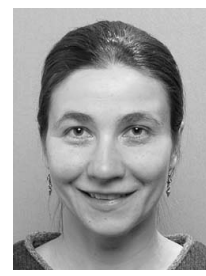

Madeleine Gibescu received her Dipl.Eng. in Power Engineering from the University Politehnica, Bucharest, Romania in 1993 and her MSEE and Ph.D. degrees from the University of Washington, Seattle, WA, U.S. in 1995 and 2003, respectively. She has worked as a Research Engineer for ClearSight Systems, and as a Power Systems Engineer for the AREVA T\&D Corporation She is currently an Assistant Professor with the Department of Electrical Power Engineering, Delft University of Technology, The Netherlands.

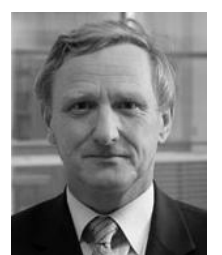

Wil L. Kling received the M.Sc. degree in electrical engineering from the Eindhoven University of Technology, the Netherlands, in 1978.

From 1978 to 1983 he worked with Kema, from 1983 to 1998 with Sep and since then up till the end of 2008 he was with TenneT, the Dutch Transmission System Operator, as senior engineer for network planning and network strategy. Since 1993 he is a part-time Professor at the Delft University of Technology and since 2000 also at the Eindhoven University of Technology, the Netherlands. From December 2008 he is appointed as a full professor and chair of Electrical Power Systems group at the Eindhoven University of Technology. He is leading research programs on distributed generation, integration of wind power, network concepts and reliability issues.

Mr. Kling is involved in scientific organisations such as Cigre and IEEE. $\mathrm{He}$ is the Dutch Representative in Study Committee C6 Distribution Systems and Dispersed Generation and the Administrative Council of Cigre. 